August 21, 2003

\title{
Endogenous wage rigidity
}

\author{
By Jonas Agell and Helge Bennmarker ${ }^{\#}$
}

We use a random survey of Swedish human resource managers to study the reasons for wage rigidity. Our findings are as follows. First, during the exceptional recession of the 1990s only 1.1 percent of workers received a wage cut. Second, much wage rigidity can be traced to behavioral mechanisms involving negative reciprocity, relative wage comparisons and money illusion. Third, the reasons for wage rigidity differ significantly between large and small establishments, and between the high- and low-end of the labor market. Fourth, there are significant empirical complementarities between efficiency wage mechanisms and worker bargaining strength, and between "exogenous" institutions and endogenous sources of wage rigidity. Fifth, external pay comparisons are a more important source of rigidity in highly unionized establishments. Sixth, there are significant gender differences in pay bargaining and work moral.

JEL classifications: E24, J30, J50, C81

Keywords: wage rigidity; survey evidence; matched data, reciprocity; behavioral macroeconomics, labor law

\footnotetext{
\# Agell: Department of Economics, Stockholm University, SE-10691 Stockholm, Sweden, email: JA@ne.su.se; Benmmarker: IFAU, Box 513, SE-75120 Uppsala, Sweden, email:

Helge.Bennmarker@ifau.uu.se. We owe a great debt to Mats Bergdahl, Agneta Sandqvist and Agneta Sträng of Statistics Sweden. We thank Lars Calmfors, Louis Christofides, Armin Falk, Josef Falkinger, Ernst Fehr, Simon Gächter, Steinar Holden, Per Lundborg, Erik Mellander, Henry Ohlsson, Robert Solow, Tommy Sveen and Josef Zweimuller for helpful comments. We have benefited from presentations at IFAU, CESifo, Bank of Norway, the Universities of Cyprus, Stockholm and Zurich, Norwegian School of Economics, Annual meeting of Norwegian labor economists, European Science Days in Steyr, the National Mediation Office, and the Swedish Ministry of Finance. We thank IFAU for financial support. An extensive documentation of our survey, and a sensitivity analysis of some of the results reported here, is provided in Agell and Bennmarker (2002).
} 
The question of why wages appear rigid in spite of high unemployment is central to macroeconomics. It is also a key ingredient in discussions about the appropriate stance of fiscal and monetary policy, the need for European labor market reform, etc. Despite the important issues at stake there is still little agreement on the empirical relevance of the models proposed in the theoretical literature. A recent literature uses surveys of those who set wages to discriminate between models. ${ }^{1}$ Many wage setters agree that much rigidity can be traced to endogenous mechanisms, unrelated to government regulation and union power. Many wage setters also attribute a primary role to fairness, gift exchange and money illusion. Based on such findings it has been argued that macroeconomic theory ought to be reformulated along behavioral lines, see Howitt (2002).

Though the burgeoning survey literature provides useful insights, it is necessarily subject to methodological problems. Some studies cover very few firms (Kaufman (1984) and Blinder and Choi (1990)), or focus on narrowly defined sectors (Agell and Lundborg (1995, 2003)). Most studies focus on large firms. ${ }^{2}$ No study uses random sampling; in the most elaborate survey Bewley (1999) started by asking friends and colleagues for persons to interview. Since response rates are low non-response bias is an important issue. Finally, because of a lack of background data previous surveys have not been able to go very far in exploring causal mechanisms.

This paper addresses these issues. In cooperation with Statistics Sweden we have completed a fully representative survey of human resource managers. Our survey provides a balanced coverage of sectors of particular interest for students of wage rigidity, and we

\footnotetext{
${ }^{1}$ See Kaufman (1984), Blinder and Choi (1990), Levine (1993), Agell and Lundborg (1995, 2003), Bewley (1995, 1999) and Campbell and Kamlani (1997).

${ }^{2}$ The mean number of employees for the firms interviewed by Blinder and Choi (1990) and Agell and Lundborg (1995) was 5767 and 1154, respectively. Bewley (1999) oversampled large companies, and interviewed the smallest firms only by accident. The sub-sample of 73 smaller firms surveyed by Campbell and Kamlani (1997) refers to firms with less than 1000 employees that were situated in a certain geographical area, and had a connection to the authors or to Colgate University. Kaufman (1984) focuses on small firms, but his 26 firms were not drawn at random, and they were concentrated to certain geographical areas. Levine's (1993) sample consists of 139 compensation managers in the very largest US companies.
} 
include a large number of firms in all size categories. We have a very high response rate of 75.1 percent, and non-response bias appears to be a negligible issue. Via Statistics Sweden we have rich background information about responding firms and their workers; this allows us to identify many regularities that we have not seen described in the preceding literature. Finally, the Swedish recession of the 1990s offers an ideal environment in which to study high-unemployment/low-inflation behavior, see Figure 1. Between 1990-94 unemployment (inclusive of those in labor market programs) increased from 2.8 to 13.6 percent. ${ }^{3}$ When we conducted our survey in the Spring of 1999 unemployment was still almost ten percent. Inflation was virtually zero; in the preceding five-year period average inflation was one percent, with little variation between years.

Our main results are as follows. First, during the economic bust of the 1990s only 1.1 percent of workers received a wage cut. Second, much wage rigidity can be traced to behavioral mechanisms involving negative reciprocity, relative wage comparisons and money illusion. Third, the reasons for wage rigidity differ significantly between large and small firms, and between the high- and low-end of the labor market. Fourth, there are strong empirical complementarities between efficiency wage mechanisms and bargaining mechanisms, and between "exogenous" institutions and endogenous sources of wage rigidity. Fifth, pay comparisons are a more important reason for wage rigidity in unionized firms; we view this as an indication that relative wage theories of rigidity are of greater relevance for Europe than for the United States. Sixth, there are significant gender differences in pay bargaining and work moral.

The next section presents our survey design and method of analysis. Section II documents the pervasive nature of wage rigidity in Sweden. Section III deals with the role

\footnotetext{
${ }^{3}$ During the first half of the 1990s the rate of job destruction was quite high in all sectors. According to the Labor Force Survey of Statistics Sweden, the number of employees decreased by 24 percent in manufacturing, by 19 percent in public administration, and by 16 percent in unskilled services (hotel and restaurants). For an extensive discussion of the Swedish crisis of the 1990s, see Lindbeck (1997).
} 
of country-specific institutions, and Section IV presents our evidence on the sources of endogenous rigidity. Section $\mathrm{V}$ turns to the issue of gender. A final section sums up.

\section{Survey design and statistical analysis}

Our sampling frame is the Business Register of Statistics Sweden, which includes the addresses to all workplaces in Sweden (877,768 establishments in 1999). We included four sectors in our sampling frame, selected to provide enough variation to cast light on various theories. Manufacturing has been at the center of attraction in much previous research. Skilled services (computer consultants, law firms, etc) is of interest because it represents a segment of the labor market with complicated jobs, and where models of work-life incentives and promotion tournaments might be of particular relevance.

Unskilled services (hotels and restaurants) is a sector with simple jobs, and in the absence of unions and government regulations the forces of demand and supply ought to matter a lot. Since we wanted to pay attention to differences between profit maximizing units and those that operate under other constraints we also included public sector administration. Since standard models of wage setting are probably less applicable for the smallest units, often run by a family, we excluded all units with less than five employees. After these exclusions, we were left with 29,782 establishments, divided among four sectors, and employing 1.14 million people (i.e. 28 percent of total Swedish employment). After dividing the remaining units in three size categories, we obtained the twelve strata of Table A1 in the Appendix. Cost considerations limited our sample to 1200 units, and we assigned a random sample of 100 to each stratum. ${ }^{4}$ Statistics Sweden sent out our questionnaire in March 1999. After three written reminders, we obtained 885 useable

\footnotetext{
${ }^{4}$ Adherence to the rule of thumb that sample size should be proportional to the number of units in each stratum suggests that a large share of the sample should be allocated to the smallest units. But we would then get less reliable responses from the largest units employing thousands of employees.
} 
replies, including answers from 300 units with less than 20 employees. This implies a very high response rate of 75.1 percent. Furthermore, Agell and Bennmarker (2002) show that the responses of late responders do not differ significantly from those of the immediate responders. We conclude that non-response bias is not an issue.

All questions are closed ones, and we asked respondents to indicate their replies on an ordinal scale, with four or five options. ${ }^{5}$ An accompanying letter promised that respondents' anonymity would be preserved, and we asked for the cooperation from the human resource manager or someone with corresponding function. While some previous surveys asked respondents to react to a selection of theories of wage rigidity, most of our questions concern concrete issues of work and pay, and we emphasized that we were interested in understanding practices at the respondent's own unit. Like Bewley (1999) we tried to avoid hypothetical questions, and questions that required respondents to assess the general equilibrium implications of firm-level wage setting. We did not always make a distinction between mechanisms generating real and nominal rigidity. First, in the presence of small frictions that make it costly to change nominal prices, the mechanisms that generate real rigidity will also generate nominal rigidity; see Ball and Romer (1990). Second, in an environment of near-zero inflation it is difficult to distinguish between mechanisms generating real and nominal rigidity. Third, as noted by Campbell and Kamlani (1997, p. 764), the distinction between real and nominal wages has little meaning when asking firms why they do not lower wages during a recession, or how the internal wage structure affects effort and work morale.

To uncover response patterns we estimate ordered logit models, regressing managers' replies on the set of background variables shown in Table $1 .{ }^{6}$ Most of these

\footnotetext{
${ }^{5}$ Agell and Bennmarker (2002) contain an English translation of the questionnaire.

${ }^{6}$ Our background variables come from three sources. First, the business register contains information about sectoral classifications, size, location, etc. Second, we asked managers about union density, pay systems and
} 
variables (including the dummies for sectoral affiliation) might appear in an ordinary earnings-equation, but we also include variables of special interest for students of wage rigidity. The first is unit size, measured by the number of employees. Large units may find it more difficult to monitor workers, and wage rigidity may then be associated with size because shirking is a bigger issue in large units. Alternatively, to the extent that larger units are more sensitive to work disruptions, worker bargaining power may be greater in larger units. We also include a measure of union density, and the share of employees on a permanent employment contract. The idea behind the latter variable is that workers' bargaining power ought to be an increasing function of the share of employees with more secure jobs. Alternatively, tenured employees may have higher pay because they can be expected to have built up a larger stock of match-specific human capital.

As a consistency check, Table 2 shows the results when we regress earnings against our benchmark regressors. All coefficients are precisely estimated, and in agreement with the microeconomic wage equations for Sweden reported in Albaek et al. (1998) and Arai (2001). There is a positive and highly significant size-earnings effect, and negative effects on earnings from the shares of female and non-Nordic employees. The coefficient on the share of employees on a permanent contract has the predicted positive sign. The negative union-wage effect agrees with Arai (2001), who finds that Swedish workers who belong to a union have lower pay, and that this result remains even as he controls for a range of worker-firm characteristics. Arai reports evidence that the negative union-wage effect captures self-selection of low-ability workers into unions.

employment contracts. Third, for all but a handful of responding establishments Statistics Sweden could provide us with information about the demographic and economic characteristics of employees. 


\section{The incidence of nominal wage cuts}

The huge increase in unemployment and the return of very low inflation suggest a climate conducive to downward wage flexibility. We asked respondents whether they had cut regular base pay “... at any time during the crisis years of the 1990s". Twenty-eight units replied in the affirmative, implying that 3.2 percent of all units had cut regular pay. Wage cuts were the least common in the public sector (one unit had cut pay), and the most common in skilled services (12 units had cut pay). Simple $t$-tests reveal that wage-cutting establishments differ in important respects. They have fewer employees, they are less unionized, and they are more prone to operate a scheme of profit sharing. ${ }^{7}$

Many of the units that had cut pay had done so for a mere handful of employees, and only nine units indicated that they had cut pay for a majority of their employees. Seven of these belong in skilled services. Thus, although we cover a period of 5-6 consecutive years of very high unemployment and near-zero inflation (see Figure 1), regular wage cuts were very uncommon, and the cuts that did occur are concentrated to strata that are less important in terms of total employment. Some calculations show that our results imply that 1.1 percent of the 1.14 million workers who belong to our sample frame received a wage cut during the slump of the 1990s. ${ }^{8}$

\footnotetext{
${ }^{7}$ The average number of employees is 67.6 in the sub-sample of wage cutting units and 97.8 in the sample of non-cutters. The average unionization rates of the two sub-samples are 52.8 and 71 percent, and the average percentages of employees covered by profit sharing are 64.3 and 30.7 percent.

${ }^{8}$ The $95 \%$ confidence interval for this estimate is $0.5 \%-1.7 \%$. For each unit we computed the number of employees who had experienced a wage cut. To aggregate to the population level, we used each stratum's share of total employment. To compute the confidence interval we generated a bootstrap distribution with 10000 elements; see Agell and Bennmarker (2002). For comparison, Ekberg (2002) finds that 1.15 percent of all private sector white-collar workers received a cut in baseline pay between 1996-99, and Agell and Lundborg (2003) find that none of 159 large manufacturing firms had implemented a comprehensive wage cut during the Swedish recession of the 1990s.
} 


\section{Country-specific institutions}

Swedish labor law does not allow employers to impose unilateral nominal pay cuts. This is so also in a situation when the old wage contract has expired; the old contract prevails until the parties have reached a new agreement. Some recent theoretical papers show that the provision that nominal wage contracts can only be changed by mutual consent is a potentially important source of nominal rigidity, see MacLeod and Malcomson (1993) and Holden $(1994,2002)$. In addition, many Swedish workers have their wages set in a twotier system, where industry-level negotiations precede plant-level negotiations. The (minimum) wage levels specified in the industry-level agreements specify a floor, which must not be undercut by the plant-level agreement. Holden (1998) shows that two-tier bargaining can be an independent source of wage rigidity.

The following evidence suggests that institutions play a role. First, many managers indicate that job protection creates substantial costs of hirings and firings (see below). This vindicates a key assumption in the theoretical models of MacLeod and Malcomson (1993) and Holden (1994). In their models, a wage cut requires a mutual agreement between firm and worker, and the firm must not fire the worker and offer re-employment at a lower wage. It is this assumption that firing costs are large that gives workers a strategic advantage when they try to prevent a nominal wage cut. Second, two-tier wage bargaining is the least common in skilled services. Based on this, we would expect the incidence of wage cuts to be significantly higher in this sector, which is indeed the case. Third, union density is significantly lower among wage cutting units, which is another indication that collective bargaining matters for wage rigidity.

Fourth, it is instructive to compare our results with those from countries with other institutions but a similar macroeconomic experience. In the United States, Canada and Switzerland an employer may dismiss a worker who refuses to take a wage cut, and these 
countries also underwent recessions during the early 1990s. US unemployment (as standardized by the OECD) stood at 5.6 percent in 1990, and peaked at 7.5 percent in 1992. Bewley (1999) actively sought out firms that had cut pay during the recession in Massachusetts, and he found that 24 of 235 interviewed businesses (10.2 percent) had reduced the base pay of some or all employees. Canadian unemployment stood at 8.1 percent in 1990, and peaked at 11.4 percent in 1993. Christofides and Stengos (2001) show that out of 2194 union settlements between 1991-94, 3.6 percent (80 contracts) included nominal wage cuts. Swiss unemployment stood at 1.9 percent in 1991, and had doubled in 1993. Fehr and Goette (2000) find that at most 8 percent of all Swiss workers received a wage cut.

Because data sources and methodology differ between studies it is not easy to compare wage rigidity across countries. Even so, we conclude that wage rigidity is more complete in Sweden than in the United States, Canada and Switzerland. Our finding that 1.1 percent of Swedish workers received a wage cut refers to the incidence during the complete time span of the recession, and the Swedish recession appears to have been significantly more severe than the recessions in the United States and Switzerland, and comparable to the recession in Canada. We view this as circumstantial evidence that country-specific institutions can lead to substantial downward nominal wage rigidity.

\section{Endogenous wage rigidity}

\section{A. Wage competition from the unemployed}

Will a depressed labor market make unemployed job seekers more willing to offer to work for less than the going wage? Solow (1990) argues that a social norm deters the unemployed from undercutting, and the surveys of Agell and Lundborg (1995, 2003) and Bewley (1999) suggest that undercutting is relatively uncommon. We asked: 
Does it happen that your workplace is approached by job seekers who offer to work under conditions that are inferior (lower pay, less convenient hours, poorer work environment, etc.) to those you normally offer new employees with corresponding qualifications?

In view of the severity of the Swedish recession, and because of our broad interpretation of undercutting, we expected many managers to answer in the affirmative. But in fact only 119 units (13.5 percent) indicated that they had encountered undercutters, and the incidence of underbidding was low in all sectors, ranging from 11.4 percent in public administration to 19.4 percent in unskilled services.

Though this result is consistent with the social norm argument of Solow, it is even more striking to note that 89.6 percent of the managers who had encountered undercutters indicated that they had always rejected the offer. The rejection of undercutters is a general phenomenon, pertaining to firms in very different sectors, and different size categories. The rejection rates range from 97 percent in manufacturing to 82.1 percent in public administration. The rejection rate for units with less than 20 employees is 90.2 percent, and for units with more than 200 employees it is 86.7 percent. Judged against these rejection rates, the low incidence of undercutting is not surprising. Offering to work for little pay is not a successful strategy for landing a job. ${ }^{9}$

We asked respondents to rank the reasons for rejection; see Table 3. In manufacturing and skilled services, concerns over personnel policy and internal conflict were the most important factors - factors emphasized in e.g. sociological efficiency wage models. In public administration, unions and collective bargaining contracts were more important factors. It should be noted that less than five percent of managers pointed to the

\footnotetext{
${ }^{9}$ These rejection rates coincide with experimental evidence. Fehr and Falk (1999) study a gift exchange game between firms and workers. Both workers and firms may present bids and counter-bids, and firms are not allowed to condition the wage on effort. In anticipation of a reciprocal effort bonus firms typically offered wages that were substantially above the market-clearing level, and they refused to hire workers who
} 
factor "underbidders have inferior skills." We conclude that understanding wage rigidity at the hiring margin requires that the searchlight is aimed at the firm and its incumbent employees, rather than at the job seeker.

\section{B. Wages, monitoring, and reciprocity}

A basic issue in models of motivation is whether firms can appraise work effort. For example, the shirking model of Shapiro and Stiglitz (1984) rests on the idea that wage rigidity occurs because workers try to take advantage of the imperfect monitoring capacity of managers. When we asked, "to what extent can you evaluate whether a specific employee performs satisfactorily on the job?" 50.7 percent of respondents indicated that they could evaluate performance "to a very great extent", while 49.3 percent indicated that they were less than certain about performance.

Most efficiency wage models predict that changes in external wages (the outside option) have an impact on work effort. This is true of the shirking model, but it also applies for versions of the gift-exchange model of Akerlof (1982) in which workers' reference norms extend to workers in other firms. As a test of this implication we asked: "How do you think that the work effort of your employees would be affected if wages/salaries increased in comparable companies or organizations, but stayed the same at your unit?" Figure 2 shows that a great majority (581 out of 882 managers) thought that higher external wages would lower effort. We view this as an indication that many managers perceive a strong incentive to maintain external wage relativities. This result is consistent with Keynes's (1936, p. 14) view of wage rigidity as a coordination failure in an economy where workers care about relative pay; below, we return to this issue.

offered to work for low pay. Unlike the survey evidence, however, Fehr and Falk report that unemployed workers engage in considerable underbidding, in spite of very high rejection rates. 
A large experimental literature shows that reciprocity is an important motivational factor for many people, see e.g. Fehr and Gächter (2000). There are also evidence from experimental labor markets suggesting that the risk that workers will retaliate by reducing effort makes firms unwilling to cut pay despite high unemployment, see e.g. Fehr, Kirchsteiger and Riedl (1993). We asked a question that tried to capture the essence of negative reciprocity: "In your opinion, do those of your employees who are dissatisfied with their pay normally reduce effort?" In line with the experimental evidence, 49 percent of managers replied in the affirmative, 28.9 percent answered that such a response was possible but not common, while 22.1 percent ruled out the possibility altogether.

Table 4 presents our ordered logit analysis of managers' responses to our questions on monitoring, the outside option, and negative reciprocity (the right-hand side variables include all the variables listed in Table 1). Columns 1, 2, and 4 show that there appears to be a clear pattern involving establishment size. Managers in large establishments are (i) less able to appraise work performance, (ii) more likely to identify a negative link between effort and external pay, and (iii) more likely to indicate that reciprocity is an important issue. These effects are estimated with high precision, and they survive an extended sensitivity analysis. ${ }^{10}$ Few other regressors are statistically significant. Unions might interfere with a firm's monitoring strategy, and educated workers hold more complicated jobs, but neither union density nor the share of employees with university education are statistically significant in column 1 . In the reciprocity regression (column 4), however, the share of female employees enters with a negative and statistically significant coefficient $(p$-value $<.01)$; we explore this result further below.

A straightforward shirking explanation for the size effects identified in the preceding paragraph is as follows. Since managers in larger units find it more difficult to

\footnotetext{
${ }^{10}$ Due to space constraints we refer to Table 10 in Agell and Bennmarker (2002).
} 
appraise performance, work effort in larger units should be more responsive to the outside option. For the same reason managers in larger units should find it more difficult to prevent acts of negative reciprocity. If this explanation is correct the size effects in columns 2 and 4 should not survive if we add an explicit measure of monitoring capacity to the estimating equation. However, in columns 3 and 5 we can see that the coefficients on the size variable change only marginally, and remain significant at the one-percent level, even as we add managers' own assessment of monitoring ability to the estimating equation. It appears that insufficient monitoring capacity is not the primary reason that managers in larger establishments view external pay and negative reciprocity as more important constraints for their pay policy. ${ }^{11}$ Alternatively, Encinosa, Gaynor and Rebitzer (1997) have suggested that peer pressure and group interaction effects are more important motivational devices in smaller establishments, where there is a close social distance between workers, and between workers and management. If this is true, managers in smaller establishments may benefit from binding work norms that prevents acts of negative reciprocity, and reduces the importance of the outside option.

Summarizing, two-thirds of our respondents believe that an increase in outside wages damages performance at their workplace, and almost fifty percent indicate that negative reciprocity is an important issue. We view this as clear evidence that most managers think that downward wage flexibility may have important adverse consequences for profitability. Obviously, this is the essence of efficiency wage theory. We have also identified a robust size effect, suggesting that outside wages and negative reciprocity are of greater importance in larger units. This is consistent with the size-earnings premium

\footnotetext{
${ }^{11}$ We obtained additional evidence against a shirking interpretation when we asked managers to rank the importance of different incentive devices. Few managers indicated that monitoring and supervision were important motivational tools, and these responses did not differ between large and small units; see Agell and Bennmarker (2002) for further details. Bewley (1999, p. 110) notes that most managers insisted that the shirking model "...did not describe their own behavior, but rather a bad form of management."
} 
identified in Table 2, and with our finding in Section II that regular wage cuts were the least common among larger units.

\section{Wages and voluntary turnover}

A potentially important deterrent to wage cuts is the risk that dissatisfied employees chose the exit option, quits. We asked, "In your opinion, do those of your employees who are dissatisfied with their pay normally seek employment elsewhere?". Out of 880 responding managers, 58.5 percent replied in the affirmative, 29.4 percent indicated that voluntary turnover was possible but uncommon, while 12.1 percent ruled out this possibility altogether. It appears that many managers view the risk of voluntary turnover as an important constraint on their wage policy.

Table 5 shows our analysis of the determinants of voluntary turnover. The positive coefficient on the share of employees with university education indicates that the risk of quits is greater in units with a large share of highly educated employees. The negative coefficient on the share of workers on a permanent contract is consistent with the idea that tenured employees can be expected to have built up a greater stock of match-specific human capital. The negative coefficient on the dummy indicating that the firm is situated in an area with a small local labor market suggests that workers' willingness to vote with their feet depend on opportunities offered elsewhere. The negative coefficient on the union variable indicates that the risk of voluntary turnover is smaller in highly unionized firms. To the extent that unions extract rents in the local wage bargain, this is what one should expect. $^{12}$

\footnotetext{
${ }^{12}$ The negative union-wage effect discussed in Section I is fully compatible with union rent sharing. According to Arai (2001) the negative union-wage effect in Swedish micro-data reflects self-selection of low-ability workers into unions. These low-ability workers should still earn a rent from union membership.
} 
As a sensitivity check we started with the full set of regressors of Table 1, and then eliminated insignificant variables in a stepwise procedure, starting with the least significant variable. Excluding all variables not significant at the five-percent level, both the share of workers on a permanent contract and our dummy indicating a small local labor market drop out from the final model (the latter is eliminated in the last round, with $p$-value $=$ $.055)$. Both the university and union variables are in the final model, with $p$-value $<.001$. Employees with university training are also better paid, and in column 2 we show that there is a positive and statistically significant partial correlation between earnings and the risk of voluntary turnover (since our full set of regressors includes many variables that should explain earnings, this regression only controls for sectoral affiliation).

We conclude that the risk of voluntary labor turnover is an important source of wage rigidity, and that this mechanism is particularly relevant for the high-end of the labor market, where workers are highly educated, lowly unionized and have access to a large local labor market. For comparison, Agell and Lundborg (1995) and Campbell and Kamlani (1997) report that reducing voluntary turnover is a more important explanation of wage rigidity for white-collar than blue-collar workers.

\section{Benefits and shirking}

The shirking model predicts that more generous unemployment compensation induces workers to slacken off. We asked: "How do you think that the work effort of your employees would be affected if unemployment benefits were increased?" Though a large majority believed that higher external wages led to lower effort, few respondents thought the same of higher benefits. Only 125 managers (14.3 percent) indicated that more generous benefits would induce their employees to reduce effort. But benefits might still matter for the low-end of the labor market. While only 8.3 percent of managers in skilled 
services responded that higher benefits would reduce effort, 28 percent of those in unskilled services responded the same.

Column 3 of Table 5 shows our analysis of the link between effort and benefits. The coefficients on the share of employees on a permanent contract and the share of employees with only elementary education are significant at the one-percent level. Both measures remain in the final model as we repeat the step-wise elimination test of the previous section. Thus, managers with a large share of employees on temporary contracts, and with a large share of lowly educated workers, are more prone to identify a negative link between benefits and effort. Employees who are lowly educated are also lowly paid, and column 4 shows that there is a significant negative partial correlation between average earnings and managers' perception that generous benefits are harmful to effort.

Summarizing, we do not find much evidence that benefits play a role via their impact on shirking and effort. But benefits may still matter for the low-end of the labor market, where workers are lowly educated and temporary contracts more common. Similarly, Bewley (1999) reports that though most US managers dismissed the shirking model as irrelevant, some remarked that it might apply to the market for low paid temporary labor. As noted by Bewley (1999, p. 110), this appears contrary to the spirit of the shirking model, since it was originally developed to explain why wages are pushed up above the market clearing-level in the primary labor market. 


\section{E. Bargaining, job protection and negative reciprocity}

A large class of models links unemployment and wage rigidity to the bargaining power of incumbent workers. ${ }^{13}$ An implication of all these models is that workers capture a share of the firm's surplus in the bargain. We asked:

How common is it that your employees (or their union representatives) require wage hikes because of high profits, or high ability to pay, in your firm/organization?

The answers suggest that profits/ability to pay is important in manufacturing and skilled services, and less important in unskilled services and the public sector. In manufacturing and skilled services 43.5 and 48.2 percent of managers indicated that workers often require higher wages in times of high profits/ability to pay. In unskilled services and public administration, the numbers were 20.9 and 17.0 percent.

We used these answers to create a proxy-variable for the rent sharing, or bargaining strength, of employees. We classified establishments on an ordinal scale, depending on the importance of profits/ability to pay in the local pay bargain, and used this measure as the left-hand side variable in our econometric analysis. ${ }^{14}$ Table 6 , column 1, shows that both establishment size and share of employees on a permanent contract show up with positive signs. These variables are significant at the five-percent level (or more), and survive our step-wise elimination test. The coefficient on the union variable has a positive sign, but the standard error is large $(p$-value $=.131)$. Finally, we estimate a statistically significant gender effect (discussed below): establishments with a large share

\footnotetext{
${ }^{13}$ In the efficient bargaining model of McDonald and Solow (1981) worker bargaining power has no effect on employment.

${ }^{14}$ Our argument is that in an establishment where the employer has all the bargaining power workers would never ask for higher wages because of high profits/ability to pay, while the opposite would apply in an establishment where employers have little bargaining power. Our measure of employee bargaining strength is correlated with earnings; in an OLS earnings equation with sectoral and geographical controls its coefficient is positive, and significant at the one-percent level.
} 
of female employees are less prone to indicate that profits/ability to pay is an important factor in the local wage bargain.

Columns 2-5 examine two additional issues. First, many theoretical bargaining models predict that strict job protection will increase wage pressure and lower employment, for the reason that job protection strengthens the bargaining position of incumbent workers; see Bertola (1999) for a discussion. To assess whether managers viewed job protection as an important factor we asked how job security affected the screening of job applicants, and 54 percent indicated that job protection to a "very great" or "great" extent boosted their screening effort. Another 38 percent indicated equally strong support for the proposition that job security lowered their propensity to hire people in an economic upturn, and increased the propensity to rely on overtime hours. In columns 2 and 3 we add the responses to these questions to the estimating equation. The coefficients on both measures are positive, precisely estimated ( $p$-values are .001 for both coefficients), and robust with respect to the step-wise elimination procedure. Managers indicating that job protection creates important effects are more prone to indicate that employees bargain for higher wages in times of high profits/ability to pay. These correlations fit the predictions from a large class of insider-outsider models.

Second, Summers (1988) argues that the presence of efficiency wage mechanisms magnify greatly the effects of worker/union bargaining power. In an “...efficiency wage environment, firms that are forced to pay their workers premium wages suffer only second-order losses. In almost any plausible bargaining framework, this makes it easier for workers to extract concessions" (Summers (1988, p. 386)). Our finding that establishment size is highly correlated with our measure of bargaining strength as well as with our indicator of negative reciprocity appears to corroborate this conjecture. To further explore this issue we added the responses to our questions on negative reciprocity 
and voluntary labor turnover to the estimating equations, see columns $4-5$. The estimated coefficients on these variables are positive, statistically significant, and robust with respect to the step-wise elimination procedure. Managers indicating that negative reciprocity and voluntary turnover are important factors also tend to indicate that profits/ability to pay is of great importance in the local pay bargain.

Summing up, many managers indicate that wage claims are responsive to profits and ability to pay. This finding is consistent with a main implication from a large class of bargaining models of unemployment and wage rigidity. We have also reported evidence that worker bargaining power is reinforced by efficiency wage mechanisms involving reciprocity and voluntary turnover, and by strict job protection. These possibilities are seldom acknowledged in theoretical models of wage bargaining.

\section{F. Workers' wage norms, unions, and Keynes's explanation}

A classic explanation of wage rigidity is the argument of Keynes (1936, p. 14) that workers care about relative wages. Because of this they oppose nominal wage cuts, unless wages can be cut in a coordinated manner throughout the economy. If such comparisons are to generate more than a limited amount of wage rigidity, they should extend beyond workers in the same firm. Surveys among US managers suggest, however, that employees mainly pay attention to the internal wage structure. Campbell and Kamlani (1997, p. 780) report that workers' notion of fair pay depend on own past wages, firm's profits, and wages of other workers in the same firm. Bewley (1998, p. 485) concludes that Keynes's theory is off the mark, since workers in the firms he approached had "...little systematic knowledge of pay rates at other firms".

In sharp contrast to this evidence, most Swedish managers indicate that both internal and external wages are important considerations in the local wage bargain. Across all strata, 
47.3 percent indicated that internal wage comparisons "always" or "frequently" played an important role, and 41.8 percent said the same about external wages. What can explain this difference between US and Swedish field surveys? Bewley (1998) conjectures that unions might play a role, and he notes that the precision of the information about external pay appears to be higher among workers in unionized firms. There is substantial variation in our union variable, with 404 establishments indicating that union density exceeds .9, and 91 establishments indicating that union density is below .1. This variation allows us to identify any union effects on wage norms with some precision. The first two columns of Table 7 show our analysis of the determinants of wage norms. Union density is positively and significantly correlated with the intensity of both internal $(p$-value $=.018)$ and external $(p$ value $=.008)$ wage comparisons. In our step-wise regressions union density stays in the final model, with $p$-value $=.01$ in both equations.

Among the other regressors establishment size enters with statistically significant coefficients in both columns (these effects survive our step-wise regressions). These correlations, suggesting that wage relativities are a bigger issue in large firms, are in line with our previous finding that efficiency wage mechanisms play a more important role in large establishments. The coefficient on the share of employees with a university education is positive and significant at the ten percent level in column $2(p$-value $=.055)$. When we eliminate regressors not significant at the five-percent level, our university measure remains in the final model with $p$-value $<.01$. This result agrees with Andrews and Henry (1963), who report that interest in external pay increases with the job level. Finally, the coefficient on the share of female employees is negative and statistically significant in both columns 1 and 2 . We return to the possible role of gender in shaping wage norms in the next section. 
We obtained further support for the view that Keynes's explanation of wage rigidity holds more promise for unionized firms when we asked directly how well the following coincided with managers' experience at their own establishment:

Some researchers argue that the reason why wages seldom fall is that wage relativities might be altered. Employees try to protect their position in the wage hierarchy, and they resist wage cuts because they are afraid that they will fall behind other employees, at their own or other units.

Almost 49 percent indicated that this mechanism coincided "completely" or "to a great extent" with their own experience. ${ }^{15}$ Column 3 of Table 7 shows that there is a significant partial correlation between the share of employees belonging to a union and respondents' appreciation of Keynes's theory. In the step-wise regression, union density remains in the final model, with $p$-value $=.006$.

We view these results as an indication that relative wage theories of rigidity offer greater promise for unionized European economies than for the United States. It is of interest to note that Keynes's view on wage rigidity appears to be based on the British experience in the 1920s, when unions played a much more important role than has ever been the case in the United States. Keynes (1925) is a publication preceding The General Theory, which explains British miners' resistance to wage cuts in terms of wage fairness.

\section{G. Money illusion}

Money illusion is often taken to mean that agents have preferences defined over nominal rather than real outcomes. The surveys of popular attitudes of Kahneman, Knetsch, and Thaler (1986) and Shafir, Diamond, and Tversky (1997) suggest that money illusion is an

\footnotetext{
${ }^{15}$ For comparison, when we asked a similar question about the labor turnover version of the insider-outsider model, only 14 percent of respondents indicated that this model coincided "completely" or "to a great extent" with their own experience. For further details, see Agell and Bennmarker (2002).
} 
important phenomenon. Similarly, Bewley (1999) observes that many managers were convinced that their employees would consider a nominal wage cut as highly unfair, even as an insult. We asked managers to react to the following scenarios, adapted from Kahneman, Knetsch, and Thaler (1986, p. 731):

Scenario 1 (872 respondents). Assume hypothetically that your enterprise is making a small surplus. There is no inflation, and unemployment is high. There are many job seekers applying for a job at your unit. Under these circumstances you decide to propose a pay cut of 5\%. How do you think that your employees would find this proposal?
Acceptable
$5.7 \%$
Not acceptable $94.3 \%$

Scenario 2 (861 respondents). Assume hypothetically that your enterprise is making a small surplus. Inflation is $10 \%$ percent, and unemployment is high. There are many job seekers applying for a job at your unit. Under these circumstances you decide to propose a pay increase of only 5\%. How do you think that your employees would find this proposal?

$$
\text { Acceptable } \quad 49.6 \% \quad \text { Not acceptable } 50.4 \%
$$

Although both scenarios have identical real implications, many managers responded that their employees would find it easier to accept a reduction in real wages that occurs through inflation, than through a nominal pay cut. ${ }^{16}$ These results are strikingly similar to those reported by Kahneman, Knetsch, and Thaler (1986). In their telephone survey of randomly selected residents of Toronto and Vancouver, 62 percent indicated that it was "unfair" to cut nominal pay under the circumstances of scenario 1, while only 22 percent thought the same about the five percent pay rise in scenario 2 .

It was probably difficult for our managers to come up with well-founded answers to our hypothetical scenarios. Yet, we find it interesting that professional wage setters are

\footnotetext{
${ }^{16}$ In the scenarios of Kahneman et al., the firm cuts pay under scenario 1, and increases wages by less than inflation under scenario 2. Since there are legal obstacles to unilateral wage cuts in Sweden, we chose a different phrasing. Our firm proposes a certain wage change, and we asked the respondent to assess "...how your employees would find this proposal". Managers were asked to rate their employees' reactions to the two scenarios according to the following five alternatives: entirely unacceptable, highly unacceptable,
} 
as convinced that money illusion is an important phenomenon in the labor market as the student- and laymen-populations that participate in surveys and experiments. Shafir, Diamond and Tversky (1997) survey people in shopping malls and an airport, and report evidence from surveys of undergraduate students at Princeton University. Fehr and Tyran (2001) report experimental results on money illusion; subjects are undergraduates at the University of Zurich.

To analyze the determinants of money illusion we estimated a (maximum likelihood) logit model, where the left-hand side variable took the value of 1 or 0 depending on whether the manager indicated that employees suffered from money illusion. This exercise showed that none of the background variables of Table 1 turned out to be statistically significant at the five-percent level. This suggests that money illusion is a general phenomenon, which does not link up with observable worker-firm characteristics.

\section{The role of gender}

A large literature analyzes the role of gender in the labor market; see e.g. Altonji and Blank (1999). Our regressions have produced regularities that we have not seen discussed in this literature. Managers in units with a large share of female employees are less likely to indicate that disgruntled employees respond by reducing effort (Table 4), and that profits/ability to pay (Table 6) and wage comparisons (Table 7) play an important role in the wage bargain. One possible explanation for these findings is that the share of female employees simply picks up differences in unmeasured worker-firm characteristics. To address this issue Table 8 shows the effect of successively adding more worker-firm controls to the estimating equation. The idea is that if the share of female employees picks 
up differences in unmeasured worker characteristics/working conditions the coefficient on female should become smaller and less statistically significant as we move down the table. The first row shows the results from an ordered logit regression where the share of female employees is the only regressor. Row 2 adds the continuous controls of Table 1 , rows 3 and 4 add one- or two-digit controls for sectoral affiliation, row 5 adds our measure of monitoring ability, and row 6 adds information about firms' pay systems.

In columns 1 and 2 we can see that there is a negative and highly significant univariate correlation between the share of female employees and the importance attached to profits/ability to pay and external wages in the wage bargain. As we expand the number of controls in rows 2-6 the coefficients on share of female employees stay approximately unchanged, and precisely estimated. Column 3 shows that the univariate correlation between share of female employees and our measure of negative reciprocity is numerically small, and not significantly different from zero. The following rows show that this is entirely due to the omission of other covariates. In rows 2-6 the coefficient on the share of female employees is statistically significant at the five- or one-percent levels. Unless the variation in remaining unmeasured worker/firm characteristics is more important than the variation in measured worker/firm characteristics that we control for in Table 8 the conclusion seems to be that gender has an independent impact. In our sample establishments with a large share of female employees have lower earnings, an effect that survives even as we introduce a range of controls for sectoral affiliation and worker-firm characteristics (see Table 1). The results reported in this section suggest that part of the explanation might be that (i) women are less aggressive wage bargainers, in the sense that they pay less attention to external wages and profits/ability to pay, and (ii) that women 
feel greater loyalty to their employer, in the sense that they are less prone to counter a perceived wage inequity with acts of negative reciprocity.

Though we acknowledge the speculative nature of these conclusions, some recent evidence point in a similar direction. Säve-Söderbergh (2002) uses unique data about requested starting salaries, and offered starting salaries, for a homogenous sample of almost 4000 Swedish university graduates. Even as she controls for a wide-variety of joband worker-specific characteristics, there is a residual gender effect, indicating that women ask for lower salaries than men. Recent experimental studies indicating that men and women exhibit different degrees of "selfishness" include e.g. Eckel and Grossman (1998), who conclude that “...women are less selfish than men when confounding factors are eliminated", and Dufwenberg and Muren (2002).

\section{Conclusions}

This paper asks professional wage setters about the reasons for wage rigidity. Our methodological value added compared to previous surveys is that we use a fully representative sampling design, and that we have access to extensive worker-firm background data allowing us to identify new behavioral regularities. Our main results can be summarized as follows. First, during a prolonged recession with very high unemployment and near-zero inflation nominal wage cuts were very rare. This seems to lend support to those macroeconomists who argue that adjustments to macroeconomic shocks may take a long time. Second, we report substantial evidence that endogenous wage rigidity - including behavioral mechanisms involving reciprocity and money illusion - play an important role also in a labor market where union density is high and government regulation widespread. Third, sources of endogenous wage rigidity differ significantly between different segments of the labor market, and between firms in 
different size classes. We have also identified gender effects, which we have not seen discussed elsewhere.

Fourth, we have found much evidence that sources of wage rigidity interact. Many popular macroeconomic models trace wage rigidity to the bargaining power of incumbent workers; here, we have reported evidence that bargaining power is reinforced by efficiency wage mechanisms involving reciprocity and voluntary turnover, and by strict job protection. Similarly, it is an old argument that workers' concern about relative pay may explain why wages do not fall in spite of high unemployment; here, we have presented evidence that unions foster rigidities due to interdependent preferences. We conjecture that such interactions between "exogenous institutions" and endogenous mechanisms may be part of the reason why the Swedish wage floor is so complete. It seems like an important research topic for the future to develop theoretical models of how e.g. behavioral mechanisms of wage rigidity interact with exogenous institutions.

A final disclaimer is in order. Since there are a limited number of questions that can be added to a single survey we focus on a narrow set of issues. We emphasize mechanisms of wage rigidity that operate at the level of the establishment, and we have more questions about endogenous sources of wage rigidity than about exogenous institutions. Surveys that specifically deal with e.g. legal institutions seem like a useful complement to the present study. However, to fully explore the effects of country-specific institutions it appears that a broader survey design is called for, like sending out the same questionnaire to firms in countries with different institutions. 
Table 1. Explanatory variables used in our regression analysis

Panel A: Continuous variables

\begin{tabular}{lcccc} 
Variable & Source & Mean & Std. Dev. & No. of obs \\
\hline Log(No. of employees) & BR & 3.68 & 1.35 & 885 \\
Share of employees belonging to a union & Q & 0.70 & 0.32 & 867 \\
Share of employees on permanent contract & Q & 0.85 & 0.20 & 879 \\
Share of female employees & ER & 0.41 & 0.25 & 845 \\
Share of non-Nordic employees & ER & 0.07 & 0.12 & 845 \\
Average age of employees & ER & 39.5 & 7.2 & 845 \\
(Average age of employees) ${ }^{2} / 100$ & & & & \\
Share of employees with only elementary education & ER & 0.21 & 0.18 & 845 \\
Share of employees with university education & ER & 0.33 & 0.28 & 845 \\
\hline
\end{tabular}

Panel B: Dummy variables

Variable Description

Dummy variables indicating Responding units were classified into nine categories based on the SICsectoral affiliation $\quad$ codes: K72; K73; part of K74; D20-21 and 23-27; D28-35; D15-19, 22 and 36-37; H55; L75111-75212, 75231, 75232 and 75300; L7522175226 and $75233-75250$.

Multiunit Dummy=1 if establishment is part of multiunit enterprise

Situated in area with small- $\quad$ Dummy=1 if establishment is in area with low population density sized labor market $\quad$ (Statistics Sweden regional codes H5, H6)

Situated in area with Dummy $=1$ if establishment is in area with average population density medium-sized labor market (Statistics Sweden regional codes H3, H4)

Notes: In the third column, BR stands for the Business Register of Statistics Sweden, Q for the questionnaire, and ER for the Employment Register of Statistics Sweden. 
Table 2. The validity of our background data: OLS earnings-equation

Explanatory variables

Dependent variable: Log(Average earnings)

$\log$ (No. of employees)

$.043^{\mathrm{a}}$

(.009)

Share of employees belonging to a union

$-.127^{\mathrm{a}}$

$(.043)$

Share of employees on permanent contract

$.311^{\mathrm{a}}$

$(.057)$

Share of female employees

$-.401^{\mathrm{a}}$

$(.054)$

Share of non-Nordic employees

$-.334^{\mathrm{a}}$

$(.101)$

Average age of employees

$.160^{\mathrm{a}}$

$(.013)$

(Average age of employees) $^{2}$

$-.170^{\mathrm{a}}$

$(.017)$

$-.600^{\mathrm{a}}$

$(.083)$

$.447^{\mathrm{a}}$

$(.059)$

$-.093^{\mathrm{b}}$

$(.038)$

Other controls

See Table 1

$R^{2}$ (adjusted)

No. of observations

824

Notes: Log(Average earnings) is calculated via the tax registers, included in the Employment register of Statistics Sweden. The regression includes the full set of regressors shown in Table 1, plus a constant. Standard errors are shown in parentheses. ${ }^{\mathrm{b}}$ denotes significance at the five percent level, and ${ }^{\mathrm{a}}$ at the one percent level. 
Table 3. Most important reasons to reject underbidders

Cited reason

Percentage of respondents that rank the reason as most important in explaining why they reject underbidders

\begin{tabular}{cccc}
\hline Manufacturing & $\begin{array}{c}\text { Unskilled } \\
\text { services }\end{array}$ & Skilled services & $\begin{array}{c}\text { Public } \\
\text { administration }\end{array}$ \\
\hline
\end{tabular}

\begin{tabular}{|c|c|c|c|c|}
\hline $\begin{array}{l}\text { Violates firm's personnel policy; } \\
\text { creates internal conflicts }\end{array}$ & 41.7 & 32.6 & 37.2 & 29.5 \\
\hline No vacancies & 37.0 & 29.9 & 42.0 & 28.5 \\
\hline $\begin{array}{l}\text { Violates collective bargaining } \\
\text { agreement; unions resist } \\
\text { underbidders }\end{array}$ & 18.2 & 33.0 & 16.4 & 42.1 \\
\hline Underbidders have inferior skills & 3.1 & 4.5 & 4.5 & 0.0 \\
\hline
\end{tabular}

Notes: The percentages shown in the four columns are based on the replies of 33, 22, 26 and 25 units, respectively. 
Table 4. Monitoring ability, external pay, and the outside option

\begin{tabular}{|c|c|c|c|c|c|}
\hline & \multirow{2}{*}{$\begin{array}{l}\begin{array}{c}\text { Can evaluate } \\
\text { work } \\
\text { performance? }\end{array} \\
(1)\end{array}$} & \multicolumn{2}{|c|}{$\begin{array}{l}\text { Higher external wages lower } \\
\text { effort of your employees? }\end{array}$} & \multicolumn{2}{|c|}{$\begin{array}{l}\text { Do employees who feel } \\
\text { underpaid normally reduce } \\
\text { effort? }\end{array}$} \\
\hline & & $(2)$ & (3) & (4) & (5) \\
\hline $\log$ (No. of employees) & $\begin{array}{l}-.150^{\mathrm{b}} \\
(.061)\end{array}$ & $\begin{array}{l}.173^{\mathrm{a}} \\
(.060)\end{array}$ & $\begin{array}{l}.167^{\mathrm{a}} \\
(.061)\end{array}$ & $\begin{array}{l}.207^{\mathrm{a}} \\
(.055)\end{array}$ & $\begin{array}{l}.197^{\mathrm{a}} \\
(.055)\end{array}$ \\
\hline $\begin{array}{l}\text { Share of employees with university } \\
\text { education }\end{array}$ & $\begin{array}{l}.293 \\
(.412)\end{array}$ & $\begin{array}{l}-.147 \\
(.405)\end{array}$ & $\begin{array}{l}-.141 \\
(.406)\end{array}$ & $\begin{array}{l}.689^{\mathrm{c}} \\
(.378)\end{array}$ & $\begin{array}{l}.685^{\mathrm{c}} \\
(.378)\end{array}$ \\
\hline Share of female employees & $\begin{array}{l}-.418 \\
(.374)\end{array}$ & $\begin{array}{l}-.155 \\
(.368)\end{array}$ & $\begin{array}{l}-.176 \\
(.369)\end{array}$ & $\begin{array}{l}-.894^{\mathrm{a}} \\
(.342)\end{array}$ & $\begin{array}{l}-.949^{\mathrm{a}} \\
(.344)\end{array}$ \\
\hline $\begin{array}{l}\text { Able to evaluate work } \\
\text { Performance }\end{array}$ & & & $\begin{array}{l}-.176 \\
(.143) \\
\end{array}$ & & $\begin{array}{l}-.243^{\mathrm{c}} \\
(.131) \\
\end{array}$ \\
\hline Other controls & Table 1 & Table 1 & Table 1 & Table 1 & Table 1 \\
\hline Pseudo R-squared & .034 & .028 & .029 & .023 & .024 \\
\hline No. of obs. & 823 & 822 & 822 & 815 & 814 \\
\hline
\end{tabular}

Notes: In all columns the estimation method is maximum likelihood ordered logit. Standard errors are shown in parentheses. ${ }^{\mathrm{c}}$ denotes significance at the ten percent level, ${ }^{\mathrm{b}}$ at the five percent level, and ${ }^{\mathrm{a}}$ at the one percent level. Ability to evaluate work performance is a dummy variable defined from the answers to the question "Can evaluate work performance?" 


\section{Table 5. Voluntary turnover, and the link between benefits and effort}

\begin{tabular}{|c|c|c|c|c|}
\hline & \multicolumn{2}{|c|}{$\begin{array}{c}\text { Do employees who feel underpaid } \\
\text { normally seek other jobs? }\end{array}$} & \multicolumn{2}{|c|}{$\begin{array}{l}\text { Higher benefits lower effort of your } \\
\text { employees? }\end{array}$} \\
\hline & $(1)$ & $(2)$ & (3) & $(4)$ \\
\hline $\begin{array}{l}\text { Share of employees with only elementary } \\
\text { education }\end{array}$ & $\begin{array}{l}.540 \\
(.535)\end{array}$ & & $\begin{array}{l}1.852^{\mathrm{a}} \\
(.697)\end{array}$ & \\
\hline $\begin{array}{l}\text { Share of employees with university } \\
\text { education }\end{array}$ & $\begin{array}{l}1.472^{\mathrm{a}} \\
(.385)\end{array}$ & & $\begin{array}{l}-.265 \\
(.551)\end{array}$ & \\
\hline Share of employees belonging to a union & $\begin{array}{l}-.929^{\mathrm{a}} \\
(.276)\end{array}$ & & $\begin{array}{l}.014 \\
(.381)\end{array}$ & \\
\hline Share of employees on permanent contract & $\begin{array}{l}-.726^{\mathrm{c}} \\
(.374)\end{array}$ & & $\begin{aligned}-1.233^{\mathrm{a}} \\
(.468)\end{aligned}$ & \\
\hline $\begin{array}{l}\text { Situated in area with small-sized labor } \\
\text { market }\end{array}$ & $\begin{array}{l}-.471^{\mathrm{c}} \\
(.244)\end{array}$ & & $\begin{array}{l}.357 \\
(.337)\end{array}$ & \\
\hline Log(Average earnings) & & $\begin{array}{l}.325^{\mathrm{b}} \\
(.165) \\
\end{array}$ & & $\begin{array}{l}-.616^{\mathrm{a}} \\
(.208) \\
\end{array}$ \\
\hline Other controls & Table 1 & $\begin{array}{l}\text { Industry dummies } \\
\text { of Table } 1\end{array}$ & Table 1 & $\begin{array}{l}\text { Industry dummies } \\
\text { of Table } 1\end{array}$ \\
\hline Pseudo R-squared & .056 & .033 & .048 & .027 \\
\hline No. of obs. & 821 & 841 & 818 & 836 \\
\hline
\end{tabular}

Notes: In all columns the estimation method is maximum likelihood ordered logit. Standard errors are shown in parentheses. ${ }^{\mathrm{c}}$ denotes significance at the ten percent level, ${ }^{\mathrm{b}}$ at the five percent level, and ${ }^{\mathrm{a}}$ at the one percent level. 
Table 6. Rent sharing, firing costs, and reciprocity

\begin{tabular}{|c|c|c|c|c|c|}
\hline & \multicolumn{5}{|c|}{ Profits/ability to pay play important role in wage bargain } \\
\hline & $(1)$ & $(2)$ & (3) & $(4)$ & $(5)$ \\
\hline $\log ($ No. of employees) & $\begin{array}{l}.379^{\mathrm{a}} \\
(.058)\end{array}$ & $\begin{array}{l}.379^{\mathrm{a}} \\
(.059)\end{array}$ & $\begin{array}{l}.410^{\mathrm{a}} \\
(.060)\end{array}$ & $\begin{array}{l}.359^{\mathrm{a}} \\
(.059)\end{array}$ & $\begin{array}{l}.379^{\mathrm{a}} \\
(.058)\end{array}$ \\
\hline Share of employees belonging to a union & $\begin{array}{l}.414 \\
(.275)\end{array}$ & $\begin{array}{l}.429 \\
(.277)\end{array}$ & $\begin{array}{l}.414 \\
(.280)\end{array}$ & $\begin{array}{l}.415 \\
(.276)\end{array}$ & $\begin{array}{l}.493^{\mathrm{c}} \\
(.277)\end{array}$ \\
\hline Share of employees on permanent contract & $\begin{array}{l}.932^{\mathrm{b}} \\
(.383)\end{array}$ & $\begin{array}{l}.986^{\mathrm{b}} \\
(.386)\end{array}$ & $\begin{array}{l}.972^{\mathrm{b}} \\
(.388)\end{array}$ & $\begin{array}{l}1.002^{\mathrm{a}} \\
(.385)\end{array}$ & $\begin{array}{l}.988^{\mathrm{a}} \\
(.383)\end{array}$ \\
\hline Share of female employees & $\begin{array}{l}-1.651^{\mathrm{a}} \\
(.357)\end{array}$ & $\begin{array}{l}-1.654^{\mathrm{a}} \\
(.362)\end{array}$ & $\begin{array}{c}-1.649^{\mathrm{a}} \\
(.361)\end{array}$ & $\begin{array}{c}-1.553^{\mathrm{a}} \\
(.360)\end{array}$ & $\begin{array}{c}-1.589^{\mathrm{a}} \\
(.358)\end{array}$ \\
\hline Job protection creates important hiring costs & & $\begin{array}{l}.204^{\mathrm{a}} \\
(.063)\end{array}$ & & & \\
\hline $\begin{array}{l}\text { Job protection induces overtime at the expense } \\
\text { of new hirings }\end{array}$ & & & $\begin{array}{l}.317^{\mathrm{a}} \\
(.070)\end{array}$ & & \\
\hline $\begin{array}{l}\text { Employees who feel underpaid normally } \\
\text { reduce effort }\end{array}$ & & & & $\begin{array}{l}.163^{\mathrm{b}} \\
(.066)\end{array}$ & \\
\hline $\begin{array}{l}\text { Employees who feel underpaid normally seek } \\
\text { other jobs }\end{array}$ & & & & & $\begin{array}{l}.171^{\mathrm{b}} \\
(.069)\end{array}$ \\
\hline Other controls & Table 1 & Table 1 & Table 1 & Table 1 & Table 1 \\
\hline Pseudo R-squared & .097 & .101 & .107 & .099 & .100 \\
\hline No. of obs. & 817 & 806 & 805 & 810 & 816 \\
\hline
\end{tabular}

Notes: In all columns the estimation method is maximum likelihood ordered logit. Standard errors are shown in parentheses. ${ }^{c}$ denotes significance at the ten percent level, ${ }^{\mathrm{b}}$ at the five percent level, and ${ }^{\mathrm{a}}$ at the one percent level. The two job protection variables as well as the reciprocity and

voluntary turnover variables take on integer values from one to five, and they are defined from the answers to these questions on our questionnaire.

In alternative regressions, we defined these variables as dummy (dichotomous) variables. This did not produce qualitatively different results. 
Table 7. Workers' wage norms in the local bargain

\begin{tabular}{lccc}
\hline \hline & $\begin{array}{c}\text { Internal wage } \\
\text { structure plays } \\
\text { important role in } \\
\text { wage bargain } \\
(1)\end{array}$ & $\begin{array}{c}\text { External wages play } \\
\text { important role in } \\
\text { wage bargain }\end{array}$ & $\begin{array}{c}\text { Keynes's relative } \\
\text { wage theory is } \\
\text { relevant }\end{array}$ \\
\hline Share of employees belonging to a union & $.633^{\mathrm{b}}$ & $(2)$ & $(3)$ \\
Log(No. of employees) & $(.268)$ & $.730^{\mathrm{a}}$ & $.732^{\mathrm{a}}$ \\
Share of employees with university & $.355^{\mathrm{a}}$ & $. .274)$ & $(.267)$ \\
education & $(.057)$ & $(.056)$ & $(.0065)$ \\
Share of female employees & .306 & $.710^{\mathrm{c}}$ & .364 \\
& $(.364)$ & $-1.228^{\mathrm{a}}$ & $(.367)$ \\
Other controls & $-.591^{\mathrm{c}}$ & $(.357)$ & $(.340)$ \\
Pseudo R-squared & $(.341)$ & Table 1 & Table 1 \\
No. of obs. & Table 1 & .055 & .012 \\
\end{tabular}

Notes: In all columns the estimation method is maximum likelihood ordered logit. Standard errors are shown in parentheses.

${ }^{c}$ denotes significance at the ten percent level, ${ }^{b}$ at the five percent level, and ${ }^{\mathrm{a}}$ at the one percent level. 
Table 8. Stability analysis: coefficient on share of female employees

\begin{tabular}{|c|c|c|c|c|}
\hline \multirow[t]{2}{*}{ Model estimated } & \multirow[t]{2}{*}{ Other explanatory variables } & \multicolumn{3}{|c|}{ Dependent variables } \\
\hline & & $\begin{array}{l}\text { Profits/ability to } \\
\text { pay play important } \\
\text { role in wage } \\
\text { bargain } \\
\text { (1) }\end{array}$ & $\begin{array}{l}\text { External wages } \\
\text { play important role } \\
\text { in wage bargain } \\
\text { (2) }\end{array}$ & $\begin{array}{c}\text { Do employees who } \\
\text { feel underpaid } \\
\text { normally reduce } \\
\text { effort? } \\
(4)\end{array}$ \\
\hline 1. Ordered logit & No & $\begin{array}{c}-1.821^{\mathrm{a}} \\
(.257)\end{array}$ & $\begin{array}{l}-.740^{\mathrm{a}} \\
(.255)\end{array}$ & $\begin{array}{l}-.159 \\
(.248)\end{array}$ \\
\hline 2. Ordered logit & $\begin{array}{l}\text { Table 1, but no controls for sectoral } \\
\text { affiliation }\end{array}$ & $\begin{array}{c}-1.859^{\mathrm{a}} \\
(.285)\end{array}$ & $\begin{array}{c}-1.037^{\mathrm{a}} \\
(.280)\end{array}$ & $\begin{array}{l}-.559^{b} \\
(.270)\end{array}$ \\
\hline 3. Ordered logit & $\begin{array}{l}\text { Table 1, but one-digit controls for industry- } \\
\text { affiliation }\end{array}$ & $\begin{array}{c}-1.283^{\mathrm{a}} \\
(.315)\end{array}$ & $\begin{array}{l}-.874^{\mathrm{a}} \\
(.313)\end{array}$ & $\begin{array}{l}-.840^{\mathrm{a}} \\
(.305)\end{array}$ \\
\hline 4. Ordered logit & Table 1 & $\begin{array}{c}-1.652^{\mathrm{a}} \\
(.357)\end{array}$ & $\begin{array}{c}-1.228^{\mathrm{a}} \\
(.357)\end{array}$ & $\begin{array}{l}-.894^{\mathrm{a}} \\
(.342)\end{array}$ \\
\hline 5. Ordered logit & $\begin{array}{l}\text { Table } 1 \text {, and control for monitoring } \\
\text { capacity }\end{array}$ & $\begin{array}{c}-1.672^{\mathrm{a}} \\
(.359)\end{array}$ & $\begin{array}{c}-1.217^{\mathrm{a}} \\
(.358)\end{array}$ & $\begin{array}{l}-.949^{\mathrm{a}} \\
(.344)\end{array}$ \\
\hline 6. Ordered logit & $\begin{array}{l}\text { Table } 1 \text {, and controls for monitoring } \\
\text { capacity, share of employees on piece } \\
\text { rates, share of employees on profit sharing }\end{array}$ & $\begin{array}{c}-1.654^{\mathrm{a}} \\
(.361)\end{array}$ & $\begin{array}{c}-1.173^{\mathrm{a}} \\
(.359)\end{array}$ & $\begin{array}{l}-.834^{b} \\
(.346)\end{array}$ \\
\hline
\end{tabular}

Notes: The dependent variables were constructed from Questions 10b, 10c and 11a. In rows 5 and 6 the extra regressors are taken from the answers to

Questions 2b, 2c and 5a on the questionnaire, see Agell and Bennmarker. The table shows the estimates of the coefficient on the share of female

employees. Standard errors are shown in parentheses. ${ }^{c}$ denotes significance at the ten percent level, ${ }^{\mathrm{b}}$ at the five percent level, and ${ }^{\mathrm{a}}$ at the one percent level. 
Figure 1. Total unemployment and inflation in Sweden, 1980-2000 (Sources: Calmfors, Forslund and Hemström (2002) and Statistics Sweden)

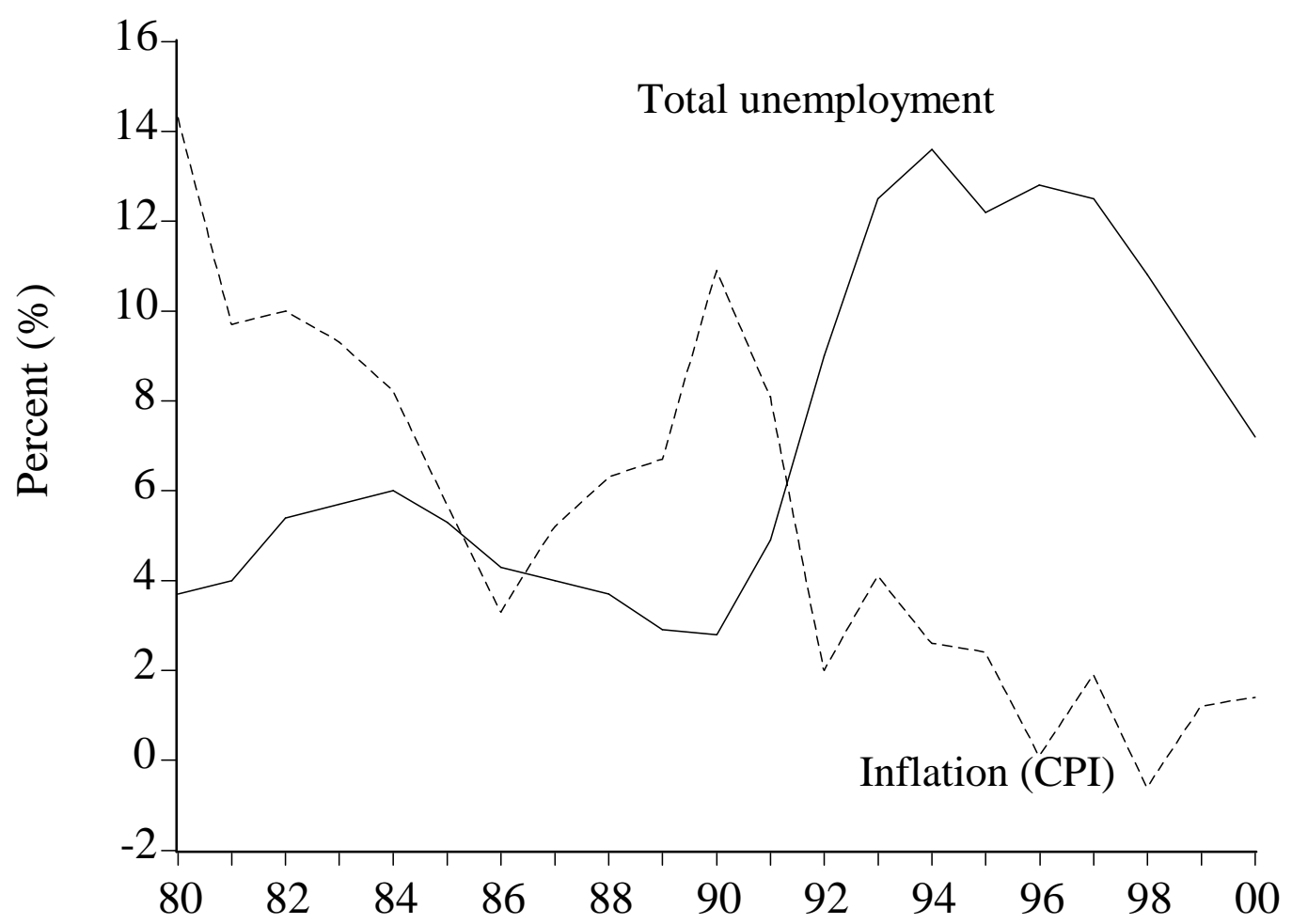


Figure 2. "How do you think that the work effort of your employees would be affected if wages/salaries increased in comparable firms or organizations, but stayed the same at your unit?" (882 respondents)

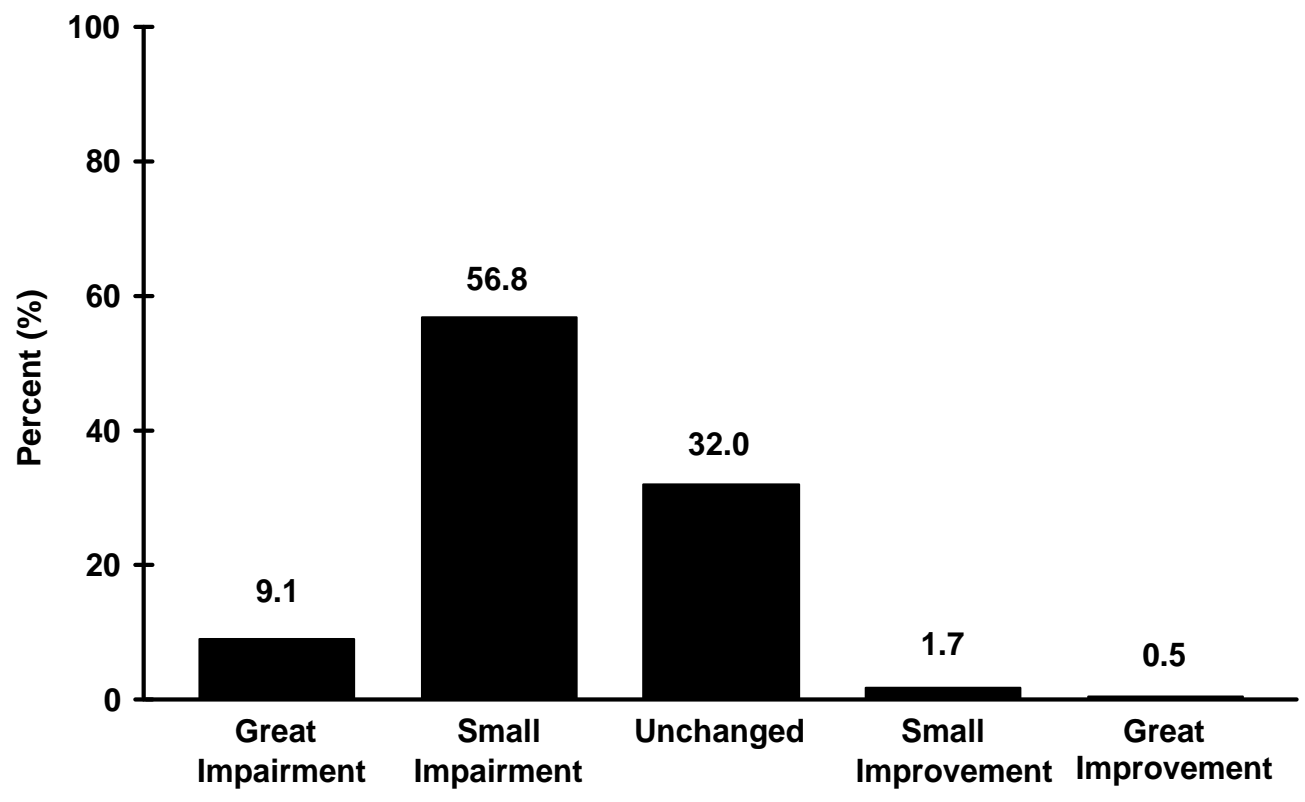




\section{References}

Agell, J. and H. Bennmarker, 2002, "Wage policy and endogenous wage rigidity: a representative view from the inside," Working Paper No. 2002:12, Institute for Labour Market Policy Evaluation.

Agell, J. and P. Lundborg, 1995, "Theories of pay and unemployment: survey evidence from Swedish manufacturing firms," Scandinavian Journal of Economics 97, 295-307.

Agell, J. and P. Lundborg, 2003, "Survey evidence on wage rigidity and unemployment: Sweden in the 1990s," Scandinavian Journal of Economics $105,15-29$.

Akerlof, G., 1982, "Labor contracts as partial gift exchange," Quarterly Journal of Economics 97, 543-569.

Albaek, K., M. Arai, R. Asplund, E. Barth, and E. Strøjer Madsen, 1998, "Measuring wage effects of plant size," Labour Economics 5, 425-448.

Altonji, J. G. and R. Blank, "Race and gender in the labor market," in Handbook of Labor Economics, volume 3C (eds. O. Ashenfelter and D. Card), Elsevier: Amsterdam

Andrews, I. R. and M. M. Henry, 1963, "Management attitudes toward pay," Industrial Relations 3, 29-39.

Arai, M., 2001, "Wages, profits and capital intensity: evidence from matched workerfirm data," forthcoming, Journal of Labor Economics.

Ball, L. and D. Romer, 1990, "Real rigidities and the nonneutrality of money," Review of Economic Studies 57, 183-203.

Bertola, G., 1999, "Microeconomic perspectives on aggregate labor markets," in Handbook of Labor Economics, volume 3C (eds. O. Ashenfelter and D. Card), Elsevier: Amsterdam

Bewley, T., 1995, "A depressed labor market as explained by participants," American Economic Review 85 (Papers and Proceedings), 250-54.

Bewley, T., 1998, "Why not cut pay?" European Economic Review 42 (Papers and proceedings), 459-90.

Bewley, T., 1999, Why wages don't fall during a recession. Harvard University Press, Cambridge (Ma.) and London, England. 
Blinder, A. and D. Choi, 1990, "A shred of evidence on theories of wage stickiness," Quarterly Journal of Economics 105, 1003-15.

Calmfors, L., A. Forslund and M. Hemström, 2002, "Does active labour market policy work? Lessons from the Swedish experience," Swedish Economic Policy Review 8, 61-124.

Campbell, C. M. and K. S. Kamlani, 1997, "The reasons for wage rigidity: Evidence from a Survey of Firms," Quarterly Journal of Economics 112, 759-89.

Christofides, L. N. and T. Stengos, 2001, "Wage rigidity in Canadian collective bargaining agreements," Industrial and Labor Relations Review 56, 429-448.

Dufwenberg, M. and A. Muren, 2002, "Discrimination by gender and social distance," Working Paper No. 2002:2, Department of Economics, Stockholm University.

Eckel, C. C. and P. J. Grossman, 1998, “Are women less selfish than men? Evidence from dictator experiments," The Economic Journal 108, 726-735.

Ekberg, J., 2002, "Nominal wage rigidity on the Swedish labor market," Licentiate thesis, Stockholm School of Economics.

Encinosa, W. E., M. Gaynor and J. B. Rebitzer, 1997, “The sociology of groups and the economics of incentives: theory and evidence on compensation systems," NBER Working Paper No. 5953, Boston.

Fehr, E. and A. Falk, 1999, "Wage rigidity in a competitive incomplete contract market," Journal of Political Economy 107, 106-134.

Fehr, E. and S. Gächter, 2000, "Fairness and retaliation: the economics of reciprocity," Journal of Economic Perspectives 14, 159-181.

Fehr, E. and L. Goette, 2000, "Robustness and real consequences of nominal wage rigidity," CESifo Working Paper No. 335, Munich.

Fehr, E., G. Kirchsteiger and A. Riedl, 1993, "Does fairness prevent market clearing? An experimental investigation," Quarterly Journal of Economics 108, 437459.

Fehr, E. and J.-R., Tyran, 2001, “Does Money Illusion Matter?” American Economic Review 91, 1239-1262.

Holden, S., 1994, "Wage bargaining and nominal rigidities," European Economic Review 38, 1021-1039.

Holden, S., 1998, "Wage drift and the relevance of centralized wage setting," Scandinavian Journal of Economics 100, 711-731. 
Holden, S., 2002, "The costs of price stability -- downward nominal wage rigidity in Europe,” NBER Working Paper No. 8865, Boston.

Howitt, P., 2002, “Looking inside the labor market: a review article," Journal of Economic Literature 40, 125-138.

Kahneman, D., J. L. Knetsch and R. Thaler, 1986, "Fairness as a constraint on profit seeking: entitlements in the market," American Economic Review 76, 728-741.

Kaufman, R., 1984, “On wage stickiness in Britain's competitive sector,” British Journal of Industrial Relations 22, 101-112.

Keynes, J. M., 1925, The economic consequences of Mr. Churchill. Reissued in 1972 in The collected writings of John Maynard Keynes, vol.IX (Essays in persuasion). London and Basingstoke: Macmillan.

Keynes, J. M.. 1936, The general theory of employment, interest and money. Macmillan, London.

Levine, D., 1993, "Fairness, markets, and ability to pay: Evidence from compensation executives," American Economic Review 83, 1241-59.

Lindbeck, A., 1997, “The Swedish experiment,” Journal of Economic Literature 35, 1273-1319.

MacLeod, W. B. and J. M. Malcomson, 1993, "Investments, holdup, and the form of market contracts," American Economic Review 83, 811-837.

McDonald, I. and R. Solow, 1981, "Wage bargaining and employment," American Economic Review 71, 896-908.

Säve-Söderbergh, J., 2002, ”Are women asking for too low wages? Gender wage differentials and individual wage bargaining," mimeo, Stockholm University.

Shafir, E., P. Diamond and A. Tversky, 1997, "Money illusion," Quarterly Journal of Economics 112, 341-74.

Shapiro, C. and J. E. Stiglitz, 1984, "Equilibrium unemployment as a worker discipline device," American Economic Review 74, 433-444.

Solow, R. M., 1990, The labor market as a social institution. Basil Blackwell, Cambridge (MA.).

Summers, L. H.,1988, "Relative wages, efficiency wages, and Keynesian unemployment," American Economic Review 78, 383-388. 
Table A1. Population, sample, and response rates

\begin{tabular}{|c|c|c|c|c|c|c|}
\hline Strata & $\begin{array}{l}\text { Total no. of } \\
\text { local units in } \\
\text { stratum }\end{array}$ & $\begin{array}{c}\text { Total } \\
\text { employment in } \\
\text { stratum }\end{array}$ & Gross sample & $\begin{array}{l}\text { Net sample, } \\
\text { after adjusting } \\
\text { for overcover. }\end{array}$ & Useable replies & Response rate \\
\hline Manufacturing, 5-19 employees & 8,745 & 82,962 & 150 & 149 & 110 & 73.8 \\
\hline Manufacturing, 20-99 employees & 3,998 & 171,330 & 100 & 98 & 77 & 78.6 \\
\hline Manufacturing, 100- employees & 1,284 & 426,451 & 100 & 99 & 83 & 83.8 \\
\hline Unskilled services, 5-19 employees & 3,090 & 27,481 & 100 & 98 & 45 & 45.9 \\
\hline Unskilled services, 20-99 employees & 894 & 33,959 & 100 & 100 & 63 & 63.0 \\
\hline Unskilled services, 100- employees & 50 & 8,154 & 50 & 49 & 32 & 65.3 \\
\hline Skilled services, 5-19 employees & 5,906 & 52,552 & 100 & 99 & 69 & 69.7 \\
\hline Skilled services, 20-99 employees & 1,606 & 60,851 & 100 & 98 & 74 & 75.5 \\
\hline Skilled services, 100- employees & 232 & 60,600 & 100 & 97 & 76 & 78.4 \\
\hline Public administration, 5-19 employees & 1,699 & 18,942 & 100 & 96 & 76 & 79.2 \\
\hline Public administration, 20-99 employees & 1,762 & 74,960 & 100 & 99 & 88 & 88.8 \\
\hline Public administration, 100- employees & 517 & 123,132 & 100 & 97 & 92 & 94.8 \\
\hline Total & 29,782 & 1141,374 & 1200 & 1179 & 885 & 75.1 \\
\hline
\end{tabular}

Notes: According to NACE, the industrial classification system of the European Union, manufacturing is group D, unskilled services group H, and Public

Administration group L. Skilled services include subgroups K72, K73, and part of K74. Since the total population of unskilled service units in the largest size

category consisted of only 50 units, we reallocated 50 random drawings to the stratum consisting of small, manufacturing units. Our net samples deviate from the

gross samples because some units ceased operation between the time our sample was drawn and our questionnaire sent out. 